\title{
PREPARATION OF HYPERIMMUNE COW COLOSTRUM WHEY AND ITS USE IN THE PROTECTION OF PIGLETS AGAINST TRANSMISSIBLE GASTROENTERITIS
}

\author{
J. ŠTĚPÁNEK, J. MENŠíK, J. FRANZ, J. KREJČí \\ Veterinary Research Institute, 62132 Brno
}

Received April 26, 1982

\begin{abstract}
Stěpánek J., J. Menšík, J. Franz, J. Krejčí: Preparation of Hyperimmune Cow Colostrum Whey and its Use in the Protection of Piglets against Transmissible Gastroenteritis. Acta vet. Brno, 51, 1982: 99-108.

Parenteral administration of porcine transmissible gastroenteritis(TGE) virus to pregnant cows resulted in the production of virus-neutralising antibodies which peaked 4 to 5 weeks after the start of immunization. Blood serum antibody titres were higher in cows immunized intravenously or subcutaneously than in those immunized into the mammary gland. Antibody concentration in the colostrum collected within 6 hours of parturition was little affected by the mode of antigen administration. In subsequent colostrum and milk samples, however, antibody titres of the cows immunized into the mammary gland were higher up to the 6th day after parturition. Regular oral administration of whey prepared from the colostrum of immunized cows had a favourable effect on the course of transmissible gastroenteritis in experimentally infected piglets and considerably reduced their mortality. As compared to controls, the treated animals had the incubation time prolonged by at least 24 hours and showed less intense clinical signs which, in sow-reared piglets, were limited to sporadic vomiting.
\end{abstract}

Pig, cattle, transmissible gastroenteritis of pigs, immunization, antibody production, colostrum, prevention.

Diarrhoeal disease of newborn piglets has been a frequent cause of morbidity and loss in pig herds. The advances in its diagnosis in recent years have made it possible to differentiate between enteropathogenic bacteria and viruses which play a major role in the aetiology of this syndrome.

The most important of the viral agents is coronavirus, which is the cause of gastroenteritis (TGE) of pigs. Although this economically important disease has received considerable attention, the views on its specific prophylaxis are still conflicting.

The infectious process in TGE remains localized to the intestinal mucosa and is unaffected by specific antibodies in the circulating blood (Hooper and Haelterman 1966; Moon et al. 1975). The only effective antibodies are those present in the gastrointestinal tract that neutralize the virus before it gains entrance to susceptible cells of the intestinal mucosa (Haelterman 1965; Hooper and Haelterman 1966; Śtěpánek et al. 1971; Bohl et al. 1972; Bohl and Saif 1975). The source of this passive local immunity of the gastrointestinal tract of suckling piglets in colostrum and milk of their immune dams (Ha elt erman 1965; Hooper and Ha elt erman 1966; Śtèpánek et al. 1971; Bohl et al. 1972; Bohl and Saif 1975). The efficiency of the specific prophylaxis depends on as to how quickly sows can be made to produce such a degree of immunity that would ensure log-term secretion of a sufficient amount of antibodies by the mammary gland.

Vaccination of sows before parturition with living or inactivated viral antigen did not yield quite satisfactory results (Tamoglia 1972), although it contributed decisively to the control of TGE in large pig herds in Czechoslovakia (Štěpánek et al. 1972). On the other hand, the protection of piglets after weaning or the protection of colostrum-deprived specific-pathogen-free (SPF) piglets remained practically an open question. Attempts to produce an effective protection by oral administration of hyperimmune and convalescent serum failed to meet the expectations (Noble 
1964; Saunders 1964). Unequivocally positive results were recorded only upon oral administration of immunoglobulins prepared from colostrum of immune sows (Stone et al. 1977). This procedure, however, is impracticable as an prophylactic and because a sufficient amount of pig colostrum is difficult to obtain.

The present study was designed to test the possibility of replacing sow's colostrum with that of cows immunized with TGE virus during pregnancy and to assess its protective effect against infection under experimental conditions.

\section{Cell Cultures}

\section{Materials and Methods}

Cell cultures were prepared by trypsinization of kidneys of 7-day-old pigs and were started from cell suspensions containing 400 to 800 thousand cells per ml growth medium (Hanks' solution with 10 per cent inactivated calf serum, 0.5 per cent lactalbumin hydrolysate and 0.1 per cent yeast extract). Infected cell cultures were maintained in Earle's medium without calf serum.

\section{Viral Strains}

TGE strain M-42 was isolated from the contents of the small intestine of diseased piglets ( $\$ těpánek et al. 1969). It was propagated and titrated in primary pig kidney cell cultures. The infected cell cultures were frozen 36 to 48 hours after infection and then thawed. Cellular debris was removed by low-speed centrifugation. The viral suspension used for immunization of the cows and for serological examination had a titre of least $10^{5}$ to $10^{6} \mathrm{TCID}_{50} / \mathrm{ml}$.

Virulent virus was isolated from a TGE outbreak in Czechoslovakia and was maintained by passage in 3- to 7-day old piglets killed 36 to 48 hours after infection. The viral suspension used for experimental infection was obtained by centrifugation (at $1000 \mathrm{rpm}$ for 30 minutes) of the intestinal contents of diseased piglets, diluted 1:10 with buffered saline.

\section{Immunization of Cows and Preparation of Hyperimmune Cow Colostrum Whey}

Cows were immunized with cell-passaged TGE strain $\mathrm{M}-42$ having to titre of $10^{5.7} \mathrm{TCID}_{50} / \mathrm{ml}$. They received it either intravenously or subcutaneously in the dose of $30 \mathrm{ml}$ or intramammarily in the dose of $80 \mathrm{ml}$ ( $20 \mathrm{ml}$ into each quarter) four times at 14-day intervals before parturition (Table 1). Blood sera collected at each immunization and colostrum and milk samples collected within 6 days of parturition were examined with the virus-neutralization (VN) test.

Hyperimmune cow colostrum whey was prepared from the colostrum collected within 24 hours of parturition from two immunized cows. Chymosin-precipitated casein and fat were removed from the colostrum by centrifugation at $5000 \mathrm{rpm}$ for 20 minutes at $4^{\circ} \mathrm{C}$. The whey thus obtained was filtered through a Seitz EK filter and stored at $-120^{\circ} \mathrm{C}$ after previous determination of VN antibody titres.

\section{Serological Examination}

Colostrum and milk samples were precipitated with chymosin to remove casein and then centrifuged at $5000 \mathrm{rpm} / \mathrm{min}$. for 20 minutes at $4{ }^{\circ} \mathrm{C}$. The wheys and blood serum samples were stored at $-20^{\circ} \mathrm{C}$ until examined.

Antibody concentration was determined by the VN test in secondary pig kidney cell cultures using plastic microplates with 96 wells and $0.05 \mathrm{ml}$ diluting loops and droppers. The VN titres were expressed as the reciprocal of the serum dilution that neutralized $100 \mathrm{TCID}_{50}$ of virus in 50 per cent of the wells.

\section{Potency Tests of Hyperimmune Cow Colostrum Whey}

(a) Experiment with Colostrum-Deprived Piglets

Ten hysterectomy-derived piglets of one litter reared in incubators on an artificial diet were divided into three groups at 4 days of age. Four piglets were given hyperimmune cow colostrum whey at 2-hour intervals and another four piglets at 4-hour intervals. The remaining two animals were left untreated to serve as controls. All the piglets were infected with the same dose of virulent virus 12 hours after the treatment was started and were observed daily for signs of clinical disease.

(b) Experiment with Suckled Piglets

Ten sow-reared piglets and 2 piglets weaned on to an artificial diet at two days of age were included in the experiment (Table 3). Hyperimmune cow colostrum whey was given orally in $5 \mathrm{ml}$ 
amounts to all sow-reared piglets every two hours. Twelve hours later 4 treated piglets and the two piglets weaned on to an artificial diet were infected with $2 \mathrm{ml}$ virulent virus. The administration of whey was withdrawn after 5 days. All the piglets were observed for signs of clinical disease.

\section{Histological Examination}

Samples for histological examination were taken from several parts of the small intestine of piglets killed during the experiment. They were fixed in formalin, stained with haematoxylin and eosin and examined particularly for atrophy of the villi.

\section{Immunofluorescent Examination}

Samples of the small intestine for immunofluorescent examination were fixed in chilled acetone and embedded in low melting-point paraffin. Sections cut on a microtome were layered with specific conjugate for 30 minutes. After being washed thoroughly in phosphate buffer, $\mathrm{pH} 7.2$, for 20 minutes, the preparations were mounted in buffered glycerol and examined under-a fluorescence microscope.

\section{Results}

\section{Production of Antibodies in Immunized Cows}

Administration of cell-passaged TGE virus to pregnant cows induced production of antibodies demonstrable in the blood sera of all the animals 14 days after immunization. The onset and dynamics of serum antibody production were little affected by the route of antigen administration. Their concentration peaked 4 to 5 weeks after commencing the immunization. The serum antibody titres recorded at this time were higher in $\mathrm{i} / \mathrm{v}$ or subcutaneously injected cows than in those which received viral antigen only by the intramammary route.

Milk and colostrum antibody titres, on the other hand, showed differences depending on the route of antigen administration. In cows injected subcutaneously or intravenously the titres were highest in the colostrum collected within 12 hours of parturition, then declined steadily so that only a very low VN activity was found in the milk collected on day 4 . Some milk samples collected on days 4 to 6 were entirely negative. In cows immunized by the intramammary route the dynamics of antibody excretion by the mammary gland was the same as in the intravenously or subcutaneously immunized animals, but the concentrations of both colostral and milk antibodies were higher. This quantitative difference was particularly marked beginning 24 hours after calving. Moreover, the antibody titres of cows immunized by the intramammary route were more sustained; they were demonstrated as a rule in the milk collected on days 4 to 6 after parturition (Table 1).

Effect of the Administration Hyperimmune Cow Colostrum Whey on the Course of Disease in Colostrum-Deprived Piglets

The typical course of disease was seen only in untreated control piglets where the first symptoms, i. e. vomiting and diarrhoea, were observed as early as 18 to 24 hours after infection. They were soon joined by accompanying signs, i. e. general dehydration and marked cachexia. The disease was fatal within 4 days. A piglet killed 36 hours after the onset of diarrhoea showed marked atrophy of the villi, and virus was demonstrated in epithelial cells of the mucosa by immunofluorescence.

The experimental animals developed signs of TGE in a substantially milder form. The protective effect of hyperimmune cow colostrum whey was manifested mainly by prolongation of the incubation period by 24 to 72 hours. A relatively 


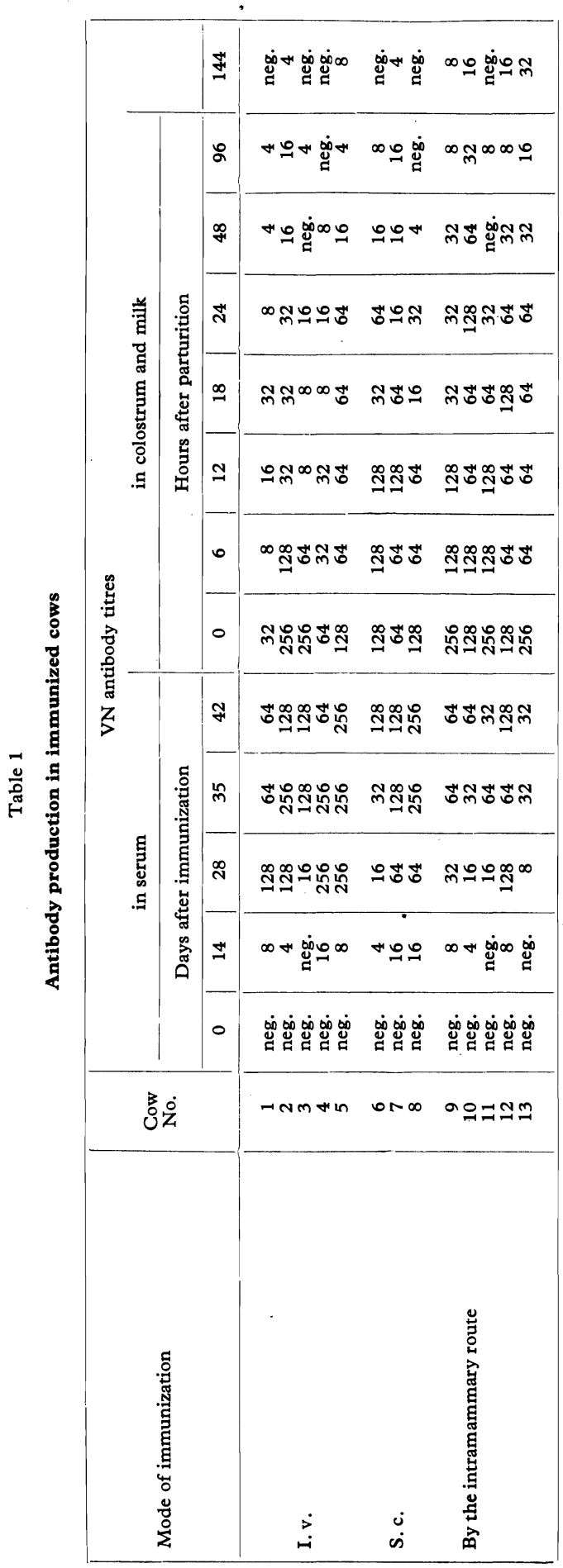




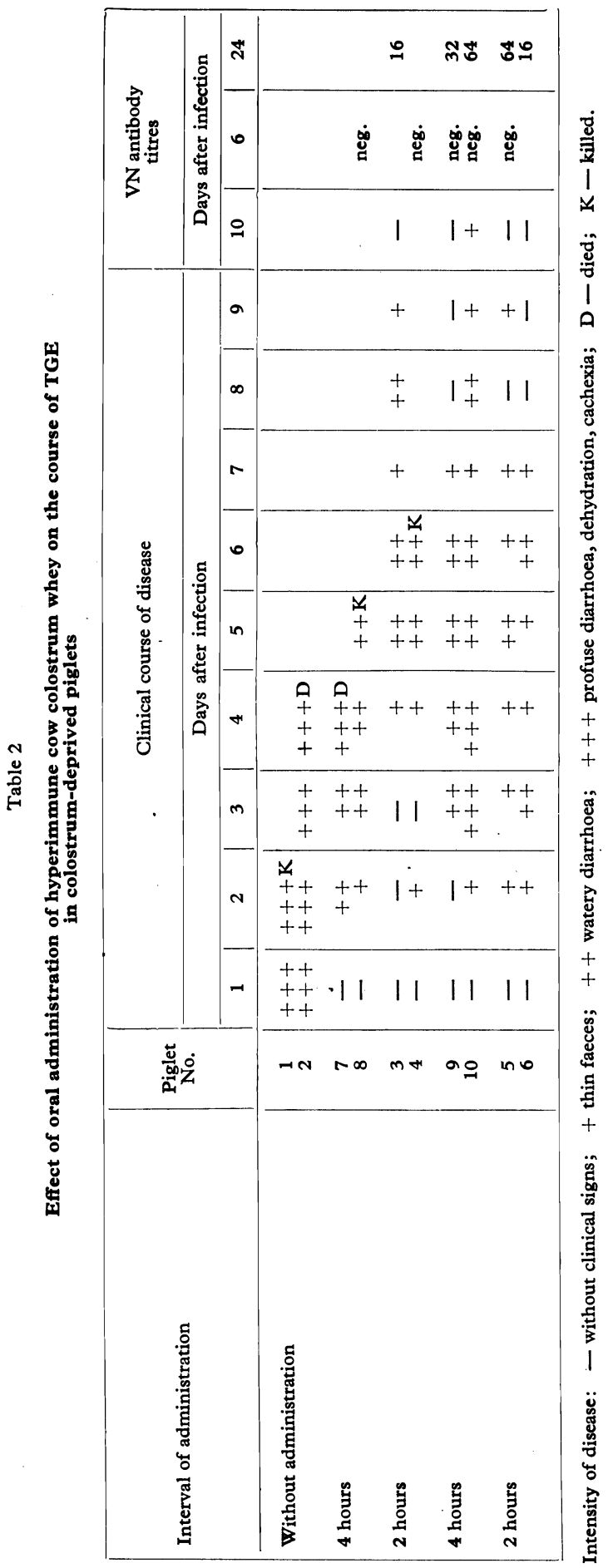




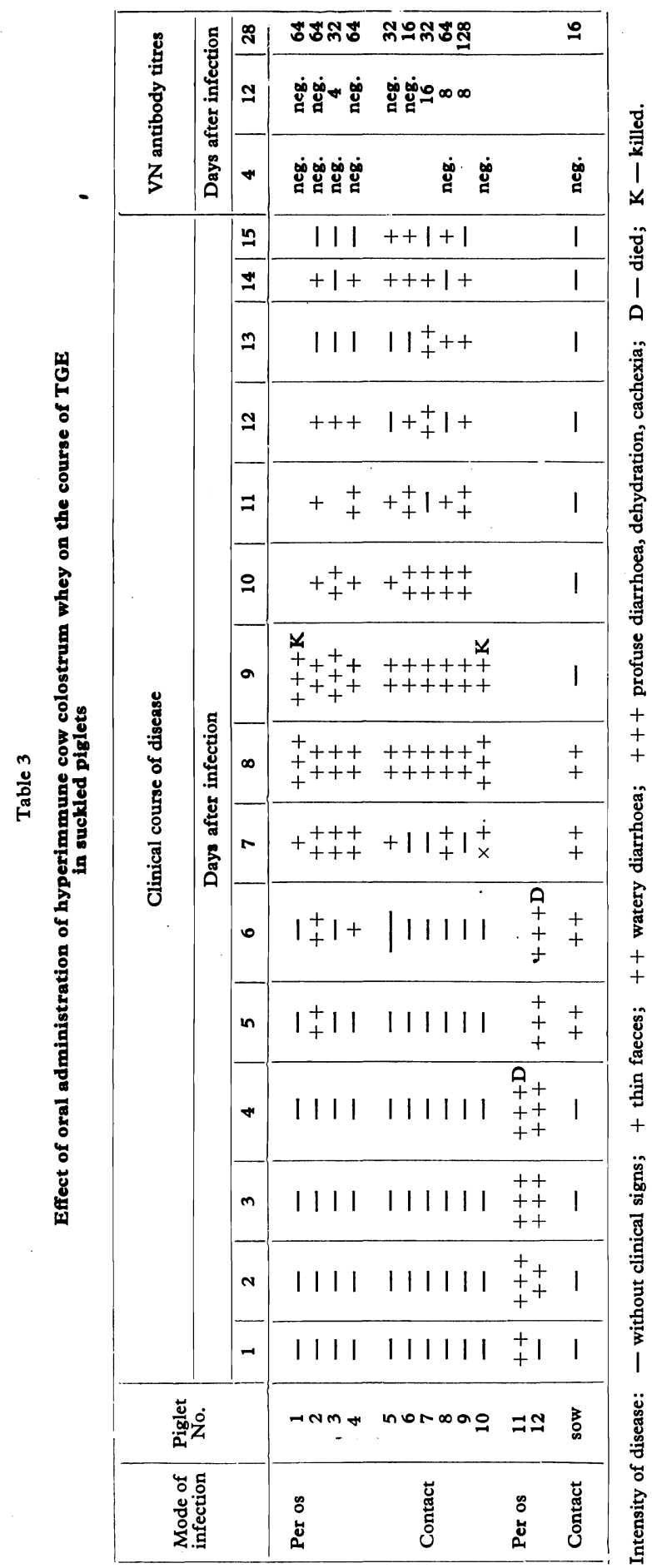


higher degree of protection was recorded in piglets that received colostrum whey at 2-hour intervals. Clinical signs were fully developed only by one piglet that was given colostral whey at 4-hour intervals; this animal died on day 4 after infection. The remaining treated piglets had their clinical signs limited to diarrhoea lasting 3 to 6 days and survived with some loss of condition (Table 2).

\section{Effect of the Administration of Hyperimmune Colostrum Whey on the Course of Disease in Suckled Piglets}

In sow-reared piglets treated with hyperimmune cow colostrum whey TGE signs were not observed until day 4 after infection and were limited to vomiting which was found with certainty in two experimentally infected piglets and in one animal exposed to contact infection. Diarrhoea did not appear until the administration of colostrum whey was withdrawn; in one animal it appeared 8 hours and in other two animals 24 hours after this withdrawal. During the next day it spread to the whole litter, its duration in individual animals varying from 3 to 10 days. Two animals were killed in this state of disease and their examination confirmed the presence of TGE infection. Both showed mild atrophy of the villi, and virus was demonstrated in cells of their mucosa by immunofluorescence. The remaining animals survived with slight loss of condition (Table 3 ).

The dam developed a profuse diarrhoea at the same time that the first piglet began scouring on day 5 after experimental infection. Her disease, accompanied by complete inappetence and hypogalactia, lasted 4 days and had a negative effect on the course of the experiment, particularly on the health status of the piglets which had to be supplemented.

Control piglets weaned from the sow and reared on an artificial diet began scour-. ing in 24 to 48 hours and died within 6 days of infection.

VN antibodies were demonstrated in the blood sera of some piglets as early as 12 days after infection and their titres showed an unequivocal tendency to rise (Table 3).

\section{Discussion}

The administration of hyperimmune cow colostrum whey had a marked effect on the clinical course of TGE. In colostrum-deprived piglets its positive effect was manifested by prolongation of the incubation period by 2 to 3 days, milder clinical symptoms and bylmarkedly reduced mortality. Suckled piglets had their symptoms limited to vomiting throughout the administration period.

The fact that the course of disease was more severe in colostrum-deprived piglets than in suckled animals was due to different conditions for the development of contact infection. The suckled piglets were kept separate from artificially reared controls and were therefore not exposed to such intense contact infection as colostrum-deprived animals that were kept in incubators together with untreated controls.

A higher degree of protection was found in piglets that were given hyperimmune cow colostrum whey at 2-hour intervals. This is apparently due to the fact that cow colostrum immunoglobulins persist in the intestinal tract in active form only for a limited length of time as was pointed out by Procházka et al. (1978). These investigations found that ${ }^{131}$ iodine-labelled cow colostral IgG $_{1}$ and its antibody fragments persisted in a small quantity in the upper part of the digestive tract for about 4 hours after oral administration and only their trace amounts 
were demonstrable in the caudal part of the small intestine and in the large intestine up to 6 hours after administration.

The disease of the sow and suckled piglets that were not experimentally infected shows that the virus multiplied in the experimentally infected piglets, although they were treated with hyperimmune cow colostrum whey, and was excreted to the environment. Indirect evidence that the infection did occur is also the antibody response found in all treated animals. That these antibodies were not absorbed from the hyperimmune cow colostrum whey is evident from the fact that they were first detected 12 days after its administration and continued to rise, although the colostrum whey was withdrawn. Active antibody production in piglets infected with TGE virus and protected against clinical manifestation of the disease by specific immunoglobulins was described also by Stone et al. (1977).

The results of the two experiments confirmed the protective effect of hyperimmune cow colostrum whey against infection taking place in the small intestine. They also direct attention to one of the possibilities of replacing lactogenic immunity which results from natural infection or vaccination of the sows (Hooper and Haelterman 1966). From the data reported by Bohl and Saif (1974) it appears that of antibodies excreted in the milk only $\operatorname{IgA}$ antibodies are effective in the intestinal lumen. St one et al. (1977), on the other hand, demonstrated a protective effect also for IgG and IgM antibodies of pig colostrum. Similarly, Noble (1964) and Saunders (1964) found a partial protection against natural TGE virus infection in piglets that were repeatedly given blood or convalescent serum of slaughter pigs per os.

The results reported here suggest that antibodies present in the colostrum of adequately immunized cows may have the same effect as antibodies contained in hyperimmune or convalescent serum and colostral whey of pigs. In this respect our observations are in keeping with the data of Lecce et al. (1976) and Bridger (1979) who prevented the development of clinical manifestation of rotavirus infection in piglets by administration of cow's milk.

The finding that cows, which are not susceptible to TGE virus infection under natural conditions, respond to parenteral administration of this virus by antibody production and that antibodies contained in their colostrum have a protective effect opens new possibilities of TGE prevention. Hyperimmune cow colostral whey can be used in all pig herds with serious rearing problems due to diarrhoea caused by TGE virus. It may prove particularly useful in the protection of older piglets and at weaning time and in the prevention of losses in herds practising early weaning or another form of rearing on an artificial diet.

The evidence published in the past few years suggests that passive local immunity of the small intestine in the young as mediated through colostrum and milk antibodies of immune dams is of value not only in TGE, but also in other gastroenteric viral infections such as rotavirus infections of piglets (Lecce et al. 1976) and lambs (Snodgrass and Wells 1976) and rotavirus and coronavirus infections of calves (Mebus et al. 1973; Woode et al. 1975). As in TGE, the infectious process of these gastroenteric viral diseases remains localized to the intestinal tract and can be affected only by antibodies present directly in the intestine. It appears probable that whey prepared from colostrum of cows immunized with various viral antigens will find application not only in the prevention of TGE, but also in the prevention and treatment of gastroenteric diseases of calves and piglets of another viral aetiology. 


\section{Příprava hyperimunní kravské kolostrální syrovátky a její využití k ochraně selat proti virové gastroenteritidě prasat}

Parenterální podáni viru virové gastroenteritidy prasat březím kravám bylo doprovázeno tvorbou virusneutralizačních protilátek, která kulminovala za $4-5$ týdnů po zahájení imunizace. V krevních sérech krav imunizovaných intravenózně a subkutánně byly zaznamenány vyšší titry protilátek než u krav imunizovaných do mléčné žlázy. V kolostru odebraném do 6 hodin po porodu nebyla koncentrace protilátek výrazně ovlivněna způsobem aplikace antigenu. $V$ později odebraných vzorcích a v mléce byly však vyšší titry protilátek, až do 6 . dne porodu, prokazovány u krav imunizovaných intramamárně. Pravidelná, perorální aplikace syrovátky připravené $\mathrm{z}$ kolostra imunizovaných krav významně ovlivnila průběh virové gastroenteritidy u experimentálně infikovaných selat a zamezila jejich hynutí. U léčených zviřat došlo $\mathrm{k}$ prodloužení inkubační doby nejméně o 24 hodin a zmírnění intenzity klinických přiznaků, které zůstaly, u selat odchovávaných pod prasnicí, omezeny jen na sporadické zvracení.

Подготовка гипериммунной коровьей молозивной сыворотки и ее применение для защиты поросят от вирусного гастроэнтерита

Парентеральная подача вируса вирусного гастроэнтерита поросят стельным коровам сопровождалась образованием нейстрализующих вирус антител, с кульминацией через $4-5$ недель после начала иммунизации. В кровяной сыворотке иммунизированных внутривенно и подкожно коров наблюдались большие титры антител, чем у коров, иммунизированных в молочную железу. В молозиве, отобранном до 6 часов после отела, концентрация антител не находилась под существенным влиянием способа подачи антигена. В позже отобранных образцах и в молоке, однако, наблюдались побольше титры антител, вплоть до 6 дня после отела, у коров, иммунизированных в молочную железу. Регулярная пероральная подача сыворотки, подготовленной из молозива иммунизированных коров, оказала влияние на протекание вирусного гастроэнтерита у экспериментально нифицированных поросят и препятствовала отходу молодняка. У леченных животных увеличилсь инкубационный период минимально на сутки и уменьшение интенсивности клинических признаков у оставшихся подсосных поросят ограничилось лишь спорадическими вротами.

\section{References}

BOHL, E. M. - GUPTA, R. K. P. - Mc CLOSEY, L. W. - SAIF, L. J. : Immunology of transmissible gastroenteritis. J. Am. vet. med. Ass., 160, 1972: 543-549.

BOHL, E. M. - SAIF, L. J.: Passive immunity in transmissible gastroenteritis of swine: immunoglobulin characteristics of antibodies in milk after inoculating virus by different routes. Infect. Immun., 11, 1975: 23-32.

BRIDGER, J C.: Protection of piglets from clinical illness caused by porcine rotavirus by feeding bovine colostrum. Report in Symposium on viral enteritis in humans and animals I. N. R. A. Grignon France, 4th-7th Sept. 1979.

HAELTERMAN, E. O.: Lactogenic immunity to TGE of swine. J. Am. vet. med. Ass., 147, 1965: $1661-1669$.

HOOPER, B. E. - HAELTERMAN, E. O.: Growth of transmissible gastroenteritis virus in young pigs. Am. J. vet. Res., 27, 1966: 286-291. 
LECCE, J. G. - KING, M. W. - MOCK, R. : Reovirus-like agents associated with fatal diarrhoea of neonatal pigs. Infect. Immun., 14, 1976: 816-825.

MEBUS, G. A. - WHITE, R. C. - BASS, E. P. - TWIEHAUS, M. J.: Immunity to neonatal calf diarrhoea virus. J. Am. vet. med. Ass., 163, 1973: 880-883.

MOON, H. W. - KEMÉNY, L. J. - LAMBERT, G. - STARK, S, L. - BOTH, G. D.: Age dependent resistence to transmissible gastroenteritis of swine. III. Effects of epithelial cell kinetics on coronavirus production and on atrophy of intestinal villi. Vet. Path., 12, 1975, $434-446$.

NOBLE, W. A.: Methods used to combat TGE. Vet. Rec., 76, 1964: 1497-1489.

PROCHÁZKA, Z. - FRÁNEK, M. - RODÁK, L. - HAMPL, J. - FRANZ, J. - MENŠIK, J.: The fate of bovine colostral $\mathrm{IgG}_{1}$ in the gastrointestinal tract of piglets. Acta vet. Brno 45 , 1976: $187-198$.

SAUNDERS, C. M.: Transmissible gastroenteritis in pigs. Vet. Rec., 76, 1964: 1504-1506.

SNODGRASS, D. R. - WELLS, P. W.: Rotavirus infection in lambs: Studies of passive protection. Archs Virol., 1976: 201-205.

STONE, S. S. - KEMENY, L. J. - WOODS, R. D. - JENSEN, M. T.: Efficacy of isolated colostral IgA, IgG and IgM to protect neonatal pigs against the coronavirus of transmissible gastroenteritis. Am. J. vet. Res., 38, 1977: 1285-1289.

ŠTĚPÁNEK, J. - MESÁROŠ, E. - POSPIŚIL, Z.: Izolace cytopatogenních kmenư původce virové gastroenteritidy prasat ve tkáňových kulturách. Vet. Med., Praha, 14, 1969: 665-674.

ŠTĚPÁNEK, J. - MENŠfK, J. - POSPIŚIL, Z. - MESÁROŠ, E.: Immunity of cows and piglets against transmissible gastroenteritis of pigs. Acta vet. Brno, suppl. 2, 1971: 69-71.

ŠTĚPÁNEK, J. - MENŠ́K, J. - ROZKOSNYY, V. - POSPIŚIL, Z.: Virová gastroenteritida prasat - vznik a vývoj imunity po přirozené a experimentální infekci a imunizaci (Project report) Brno, Veterinary Research Institute, 1972, p. 64.

TAMOGLIA, F. W.: Present status of products available for use against transmissible gastroenteritis. J. Am. vet. med. Ass., 160, 1972: 554-558.

WOODE, G. M. - JONES, J. - BRIDGER, J. C.: Levels of colostral antibodies against neonatal calf diarrhoea virus. Vet. Rec., 97, 1975: 148-149. 